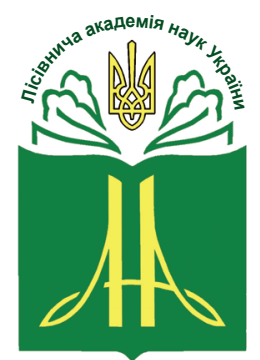

Forestry Academy of Sciences of Ukraine

Наукові праці Лісівничої академії наук України Proceedings of the Forestry Academy of Sciences of Ukraine

http://fasu.nltu.edu.ua https://doi.org/10.15421/412111

Article received 2020.12.06

Article accepted 2021.06.10

\author{
ISSN 1991-606X print \\ ISSN 2616-5015 online \\ (a) $\square$ Correspondence author \\ Yulian Kahaniak \\ kahanjak@nltu.edu.ua
}

General Chuprynka str., 103, Lviv, 79057, Ukraine

\title{
Багатомірна будова букових деревостанів північно-східного мегасхилу Українських Карпат: теоретичні аспекти і практичне значення
}

\author{
Ю.Й. Каганяк' , І.С. Ільків², С. А. Гаврилюк ${ }^{3}$
}

Дослідженнями охоплено високоповнотні одновікові високопродуктивні букові деревостани північносхідного мегасхилу Украӥнських Карпат у різному віці. Методом перелікової таксації зібрано первинну інформацію про таксаційну будову букового деревостану. Первинними даними є діаметри та висоти дерев бука, які отримано з урахуванням їхнього зв'язку в динаміиі.

Математико-статистичний аналіз первинних даних букових деревостанів дав змогу обтрунтувати основні таксаційні параметри для подальшого моделювання їх у динаміці і статиці. Моделлю розподілу діаметрів і висот вибрано рівняння вирівнювальної поверхні типу А. Функція щзільності розподілу ймовірностей циієї моделі описується 14 параметрами. Розподіл діаметрів (висот) оцінено середньоарифметичною величиною, стандартним відхиленням, асиметрією та ексиесом, а також шістьма параметрами, які зв'язують зазначені розподіли, дають змогу отримати теоретичну поверхню. За результатами моделювання 14 параметрів вирівнювальної поверхні типу А побудовано двовимірні розподіли частот за діаметром та висотою. Теорію таксаиійної будови доповнено розподілами висот з урахуванням зв'язку з діаметрами у динаміці. Поверхні розподілу частот діаметрів і висот описують структуру букових деревостанів I'-II класів бонітету в діапазоні 10-120 років.

Розрахунок запасу деревостану здійснено із застосуванням моделі багатовимірного розподілу, щзо дає змогу розиирити інформаційну основу сортиментаиії й товаризаџіï. Застосування методу багатовимірного оцінювання розподілу висоти й діаметра в різному віці, у різних лісорослинних умовах дає змогу формалізувати проектування рубок догляду, деталізувати оцінку підземної та асимілятивної частин деревостану.

Ключові слова: функція щүільності; розподіл; теоретична поверхня; параметри; деревостан; динаміка; зв 'язок.

\footnotetext{
Каганяк Юліан Йосипович - академік Лісівничої академії наук України, доктор сільськогосподарських наук, професор кафедри лісової таксації та лісовпорядкування. Національний лісотехнічний університет України, вул. Генерала Чупринки, 103, м. Львів, 79057, Україна. Тел.: +38-096-057-11-96. E-mail: y.kahanjak@nltu.edu.ua ORCID: http://orcid.org/0000-0002-9215-3922

2 Ільків Іван Стефанович - кандидат сільськогосподарських наук, завідувач кафедри лісової таксації та лісовпорядкування. Національний лісотехнічний університет України, вул. Генерала Чупринки, 103, м. Львів, 79057, Україна. Тел.: +38-067-926-45-61. E-mail: i.ilkiv@nltu.edu.ua ORCID: https://orcid.org/0000-0002-8863-8708

Гаврилюк Сергій Анатолійович - кандидат сільськогосподарських наук, доцент кафедри лісової таксації та лісовпорядкування. Національний лісотехнічний університет України, вул. Генерала Чупринки, 103, м. Львів, 79057, Україна. Тел.: +38-068-760-91-99. E-mail: serhiy_havrylyuk@nltu.edu.ua ORCID: https://orcid.org/0000-0003-0361-0624
} 
Вступ. Наукові спостереження за структурою об'єкту можна здійснювати у двох напрямах. У першому замірюють досліджувану властивість (ознаку) у кожного із сукупності однорідних об'єктів. Другий напрям передбачає визначення декількох ознак (вимірів), характерних для об'єкта (Митропольский, 1961; Яглом, Яглом, 1973).

Перший напрям досліджень, пов'язаний із вивченням розподілу окремої ознаки, достатньо представлений у лісотаксаційній і біометричній науках (Вентцель, 2001; Лакида, 1997). Методами математичної статистики формалізовано розподіли випадкової величини для діаметра, висоти та об'єму стовбура, а також інших таксаційних ознак і показників (Третяков, 1927; Митропольский, 1961; Вентцель, 2001; Цурик, 2001).

Одновікові деревостани Fagus sylvatica L. характеризуються розподілом частот діаметра (висоти) у переважній більшості одномодальними або з локальними максимумами. Гіпотеза підтверджена попередніми дослідженнями (Фелив, 1978). Розподіли такого типу повністю описуються чотирма параметрами - положення, масштабу, косості та ексцесу.

За попередніми дослідженнями, діаметри і висоти деревних порід у різному віці та у різних лісорослинних умовах найчастіше розподілені за нормальним або узагальненим нормальним законами. Існує низка моделей, які також придатні для апроксимації, але $\epsilon$ різновидом нормального та узагальненого нормального законів або подібними до них. Йдеться про такі розподіли як логнормальний, Максвелла, Вейбула, Пірсона, Джонсона, Фішера (Митропольский, 1961; Вентцель, 2001; Цурик, 2001).

Другий напрям наукових досліджень (оцінювання багатовимірних залежностей) $€$ менш результативним з об' єктивних причин. Основна причина полягає у трудомісткості збору фактичного матеріалу та громіздкості розрахунків під час апроксимації розподілу декількох випадкових сильно корельованих величин. Однак, на необхідності та перспективності наукових досліджень у цьому напрямі наголошував А.К. Митропольский (1961).

Ускладнення структурної характеристики деревостанів тісно пов'язано з сучасними науковими дослідженнями частки мертвої деревини у вуглецевому балансі (Martin, Domke, Doraisami, \& Sean, 2021); нагромадженням вуглецю лісовими екосистемами (Dudek, Korol, Havryliuk, Dychkevych, \& Bobiec, 2021); структурою намету деревостану методами космічного лазерного знімання (Sens, Spracklen, \& Spracklen, 2021); структурною складністю лісів у різних кліматичних зонах (Ehbrecht et al., 2021); оцінюванням природності старовікових деревостанів (Sens, Spracklen, \& Spracklen, 2021) та дендрометричною структурою деревостанів (Ehbrecht et al., 2021).

Методика моделювання двохмірного розподілу ймовірностей. Об 'єкт дослідження - високопродуктивні одновікові букові деревостани північносхідного мегасхилу Українських Карпат у різному віці. Предмет дослідження - таксаційна будова зазначеного об'єкта.

Мета досліджень полягала у моделюванні розподілу частот діаметрів і висот з урахуванням їхнього зв'язку у динаміці для деталізації інформації про будову букових деревостанів північно-східного мегасхилу Українських Карпат. Вихідні дані отримано внаслідок реалізації методу подеревної перелікової таксації. Ними є діаметри стовбурів дерев на висоті 1,3 м та висоти дерев бука лісового.

Аналіз сукупності діаметрів і висот (ознак) полягає у виборі функції щільності розподілу ймовірностей. Функція щільності найповніше описує зазначені сукупності. Моделювання функції щільності пов'язане із розрахунком числових характеристик (параметрів).

Статистична теорія визначила основні параметри одновимірних моделей розподілу, якими є математичне очікування, стандартне відхилення, а також асиметрія та ексцес. Чим складнішу систему вивчають, тим більше ускладнюється модель, a, отже, і зростає кількість параметрів, які ії описують. Збільшення кількості досліджуваних ознак об'єктивно ускладнює математичну модель. У цьому разі для моделювання розподілу діаметра та висоти деревостану, з урахуванням зв'язку між ознаками, необхідно застосувати від 5 до 14 параметрів.

Достовірнішу інформацію про форму двовимірного розподілу висоти та діаметра можна отримати, використавши рівняння вирівнювальної поверхні типу А, яке описують формулою (1). Нормовану величина (х) для ряду діаметра описують формулою (2), а нормовану величину (у) для ряду висоти - формулою (3):

$$
\begin{aligned}
& \varphi_{A}(x, y)=\varphi(x) \cdot\left(\varphi(y)-\frac{r_{03}}{6} \cdot \varphi^{3}(y)+\frac{r_{04}-3}{24} \cdot \varphi^{4}(y)\right)+ \\
& +\varphi^{1}(x) \cdot\left(-\frac{r_{12}}{2} \cdot \varphi^{2}(y)+\frac{r_{13}-3 \cdot r_{11}}{6} \cdot \varphi^{3}(y)\right)+ \\
& +\varphi^{2}(x) \cdot\left(-\frac{r_{21}}{2} \cdot \varphi^{1}(y)+\frac{r_{22}-2 \cdot r_{11}^{2}-1}{4} \cdot \varphi^{2}(y)\right)+, \\
& +\varphi^{3}(x) \cdot\left(-\frac{r_{30}}{6} \cdot \varphi(y)+\frac{r_{31}-3 \cdot r_{11}}{6} \cdot \varphi^{1}(y)\right)+ \\
& +\varphi^{4}(x) \cdot\left(\frac{r_{40}-3}{24} \cdot \varphi(y)\right) \\
& \quad x=\frac{1}{\sqrt{1-r_{11}^{2}}} \cdot\left(\frac{y_{j}-Y_{a}}{\sigma_{x}}-\frac{r_{11} \cdot\left(x_{i}-X_{a}\right)}{\sigma_{x}}\right)
\end{aligned}
$$

де: $\mathrm{r}_{11}$ - параметр зв'язку; $\mathrm{r}_{03}, \mathrm{r}_{30}, \mathrm{r}_{04}, \mathrm{r}_{40}$ - основні моменти різного порядку, які визначають форму кривої розподілу діаметра (висоти); $\mathrm{r}_{22}, \mathrm{r}_{21}, \mathrm{r}_{12}$, $\mathrm{r}_{31}, \mathrm{r}_{13}$ - змішані основні моменти різного порядку; $\varphi$ - функція нормального розподілу; $\varphi^{1}, \ldots, \varphi^{4}$ - похідні різного порядку функції нормального розподілу; $\mathrm{x}, \mathrm{y}$ - нормована величина для діаметра та ви- 
соти; $\mathrm{X}_{\mathrm{a}}, \mathrm{Y}_{\mathrm{a}}$ - середньоарифметичний діаметр (висота); $\sigma_{x}\left(\sigma_{y}\right)-$ стандартне відхилення розподілу діаметра (висоти).

Функція щільності нормального розподілу та чотири ii похідні описують формулами, які наведено в працях А.К. Митропольського (1961) і К.С. Венцель (2001). Ці ж вчені подають ознаки нормальності теоретичної поверхні, якими є співвідношення параметрів моделі (1): $\mathrm{r}_{30}=\mathrm{r}_{03}, \mathrm{r}_{40}=\mathrm{r}_{04}, \mathrm{r}_{12}=\mathrm{r}_{21}$, $\mathrm{r}_{31}=\mathrm{r}_{13}=3 \times \mathrm{r}_{11}, \mathrm{r}_{22}=1+\mathrm{r}_{11}^{2}, \mathrm{r}_{11}=\mathrm{r}_{31}: \mathrm{r}_{40}=\mathrm{r}_{13}: \mathrm{r}_{04}$.

На відміну від одновимірних моделей, у двовимірному розподілі типу А з'являються якісно нові параметри, що дає змогу перейти від оцінювання ознак у площині до тривимірної просторової презентації. У моделі (1) з 14 параметрів шість відповідають за оцінювання форми поверхні. Дві системи величин поєднані параметром зв'язку $\left(\mathrm{r}_{11}\right)$. Поверхня розподілу двох величин описується параметрами $\mathrm{r}_{22}, \mathrm{r}_{21}, \mathrm{r}_{12}, \mathrm{r}_{31}$ та $\mathrm{r}_{13}$.

Теоретичні значення середніх висоти $(\mathrm{H})$ та діаметра (D), а також основних моментів отримано за результатами регресійного аналізу. Прогноз середньої висоти здійснено через верхню висоту, а середнього діаметра - на основі показника $\mathrm{D} \times \mathrm{H}^{-1}$. У межах класу бонітету та середнього віку деревостану із бази даних вибрано таксаційні пробні площі 3 максимальними показниками запасу, а з-поміж них відібрано об'єкти 3 найбільшою величиною середнього діаметра. Для цих пробних площ розраховано показник $\mathrm{D} \times \mathrm{H}^{-1}$.

Встановлено тісний зв'язок між таксаційними показниками деревостану H (D) та параметрами розподілу $\mathrm{H}_{\mathrm{a}}\left(\mathrm{D}_{\mathrm{a}}\right)$. Враховуючи тісний зв'язок між параметрами положення $\left(\mathrm{r}_{11}>0,99\right)$, математичною моделлю вибрано рівняння прямої $\mathrm{y}=\mathrm{a}+\mathrm{b} \times \mathrm{x}$. На основі цієї моделі описано параметри положення для системи висоти та діаметра. Адекватну оцінку названих вище показників отримують шляхом введення в регресійну модель одного фактора (середньої висоти або середнього діаметра).

Розрахунок параметрів моделі (1) здійснено за загальновідомим у математичній статистиці алгоритмом (Вентцель, 2001). Між стандартним відхиленням ряду діаметра, середньоарифметичним та середньоквадратичним діаметрами існує функціональна залежність, яку описують відомою в біометрії формулою $\mathrm{s}_{\mathrm{d}}=\left(\mathrm{D}^{2}-\mathrm{D}_{\mathrm{a}}^{2}\right)^{0,5}$. Стандартне відхилення для ряду висоти вираховують за формулою $\mathrm{s}_{\mathrm{h}}=\left(\mathrm{H}_{\mathrm{q}}^{2}-\mathrm{H}_{\mathrm{a}}^{2}\right)^{0,5}$.

Потреба докладнішого дослідження зв'язків між різними ознаками деревостану та якісно нового рівня узагальнення виявлених тенденцій і закономірностей вимагає збільшення вимірності ймовірнісної моделі розподілу випадкової величини. Таку модель розподілу ймовірностей двох випадкових величин описують не кривою, а поверхнею розподілу.

Проекція такої поверхні на площину відображається еліпсом розсіювання ймовірностей щодо осей абсцис та ординат. Лінійне оцінювання міри стиснутості еліпса здійснюють за допомогою коефіці- єнта кореляції. Параметр зв’язку (коефіцієнт кореляції) є змішаним основним моментом першого порядку й розраховується за відомою в математичній статистиці формулою (Вентцель, 2001).

Коефіцієнт кореляції оцінює залежності між ознаками, які є близькими до лінійних. Він придатний для встановлення тісноти залежності між значеннями двох випадкових величин. Наявність істотного зв'язку не є достатньою умовою для повного опису поверхні розподілу. Параметром $\mathrm{r}_{11}$ неможливо описати форму поверхні розподілу двох випадкових величин.

Форма кривих розподілу кількості дерев за діаметром або висотою не симетрична. В окремі періоди росту показник асиметрії є сильний за ступенем, а середній - характерний упродовж тривалого часу. Скошеність та ексцес розподілів діаметра та висоти, як окремо взятих систем, позначається й на двовимірному розподілі. Форму поверхні можна оцінити внаслідок поєднання таких параметрів як $\mathrm{r}_{21}, \mathrm{r}_{12}, \mathrm{r}_{13}, \mathrm{r}_{31}, \mathrm{r}_{22}$ та похідних функції ЛапласаГаycca.

Після підбору теоретичної моделі доводимо випадковість розбіжності із емпіричною поверхнею. Це дає змогу встановити адекватність вирівнювання функцією щільності емпіричної поверхні. За критерій узгодженості фактичних і теоретичних розподілів системи двох випадкових величин, враховуючи простоту розрахунку, вибрано критерій Пірсона $\left(\chi^{2}\right)$. Гіпотезу $\mathrm{H}_{0}$ про те, що $\left.\xi=\xi_{1}, \xi_{2}, \ldots, \xi_{\mathrm{n}}\right)$ $\epsilon$ вибіркою $з$ розподілу $\mathrm{G}$ відхиляємо у тому випадку, коли виконується співвідношення (4).

$$
D\left(\hat{F}_{n}, G\right)=\sum_{i=1}^{s} \sum_{j=1}^{k}\left(\frac{\left(v_{i j}-n \cdot p_{i j}\right)^{2}}{n \cdot p_{i j}}\right)>\chi_{\alpha ;(r-1),}^{2}
$$

Отже, 3 імовірністю $\alpha$ гіпотеза $\mathrm{H}_{0}$ відхилятиметься, коли вона справджується. Якщо розбіжність D істотна, тоді ймовірність $\mathrm{P}\left(\chi^{2}\right)$ набуває малих значень. У такому разі гіпотезу про узгодженість відкидають як неправдоподібну. За умови, що $\mathrm{n} \times \mathrm{p}_{\mathrm{ij}}\left(v_{\mathrm{ij}}\right) \leq 10$, клас об'єднуємо із наступним.

Додатково висунуто гіпотезу $\mathrm{H}_{0}$ про незалежність ознак $\xi$ і $\eta$. Ії відхиляємо, якщо виконується співвідношення (5):

$$
D\left(\hat{F}_{n}, G\right)=\sum_{i=1}^{s} \sum_{j=1}^{k}\left(\frac{\left(v_{i j}-\left(\frac{v_{i \bullet} v_{\bullet j}}{n}\right)\right)^{2}}{\left(\frac{v_{i \bullet} v_{\bullet j}}{n}\right)}\right)>\chi_{\alpha ;(s-1)(k-1),}^{2}
$$

Для гіпотетичних ймовірностей $\hat{p}_{i \bullet} \hat{p}_{\bullet j}$ приналежність значень пар ознак до $\mathrm{X}_{\mathrm{i}} \times \mathrm{Y}_{\mathrm{j}}$ виконується співвідношенням $\left(\hat{p}_{i \bullet} \hat{p}_{\bullet j}\right) \cdot n=\left(v_{i \bullet} v_{\bullet j}\right) \cdot n^{-1} \geq 10$.

Результати моделювання параметрів функції розподілу частот за двома ознаками. Моделювання параметрів положення розпочинаємо із аналітичного опису динаміки середньої висоти, яку для бука лісового описують рівнянням (6), а також мо- 
делі зв'язку середньої висоти із верхньою, яка для деревного виду описана рівнянням (7):

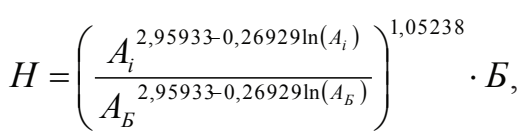

$$
\begin{aligned}
& H=0,78744 \cdot H_{B}^{1,05238},
\end{aligned}
$$

Для подальшого розрахунку необхідна інформація про середню висоту в базовому віці (Б). Базовим прийнято вік 100 років, в якому спостережено перехід величини показника висоти від рівномірного росту до його припинення. Для $\mathrm{I}^{\mathrm{c}}$ класу бонітету $\mathrm{B}=40 \mathrm{M}, \mathrm{I}^{\mathrm{b}}-\mathrm{Б}=36,3 \mathrm{M}, \mathrm{I}^{\mathrm{a}}-\mathrm{B}=32,6 \mathrm{M}, \mathrm{I}-\mathrm{S}=28,9 \mathrm{M}$.

На основі значень середньої висоти букових деревостанів та оптимальної величини показника
$\mathrm{D} \times \mathrm{H}^{-1}$ розраховано динаміку середнього діаметра за формулою $\mathrm{D}=\left(\mathrm{D} \times \mathrm{H}^{-1}\right) \times \mathrm{H}$. Середній діаметр бука описано моделлю (8).

$$
D=0,4468 \cdot \operatorname{EXP}(0.0053 \cdot \bar{B}) \cdot H^{1+2,83295^{-0,7256}},
$$

Основні статистики моделі середнього діаметра (8): сума квадратів різниць (скр) - 5398; обсяг вибірки (N) - 204; число параметрів моделі (f) - 4; число ступенів свободи (v) - 200; помилка регреciï $\left(\mathrm{m}_{\mathrm{y}}\right)-5,193$; довірчий коефіцієнт $(\mathrm{t})-1,96$; рівень імовірності (Р) - 95\%; дисперсія експерименту $\left(\sigma_{\mathrm{y}}^{2}\right)-140,72$; дисперсія адекватності $\left(\sigma^{2}{ }_{\text {зал }}\right)-27,01$; критерій Фішера фактичний $(\mathrm{F})$ - 0,19; критерій Фішера теоретичний $\left(\mathrm{F}_{5 \%}\right)-1,39$.

Результати моделювання середніх висоти і діаметра наведено в табл. 1.

Табличя 1

\begin{tabular}{|c|c|c|c|c|c|c|c|c|}
\hline \multirow{3}{*}{$\begin{array}{c}\text { Середній вік, } \\
\text { років }\end{array}$} & \multicolumn{8}{|c|}{ Значення показників за класами бонітету } \\
\hline & $\mathrm{I}^{\mathrm{c}}$ & $\mathrm{I}^{\mathrm{b}}$ & $\mathrm{I}^{\mathrm{a}}$ & I & $\mathrm{I}^{\mathrm{c}}$ & $\mathrm{I}^{\mathrm{b}}$ & $\mathrm{I}^{\mathrm{a}}$ & I \\
\hline & \multicolumn{4}{|c|}{ середня висота, м } & \multicolumn{4}{|c|}{ середній діаметр, см } \\
\hline 10 & 3,9 & 3,5 & 3,2 & 2,8 & 2,8 & 2,5 & 2,2 & 1,9 \\
\hline 20 & 10,6 & 9,6 & 8,7 & 7,7 & 9,3 & 8,4 & 7,5 & 6,6 \\
\hline 30 & 17,0 & 15,4 & 13,8 & 12,3 & 16,3 & 14,7 & 13,3 & 11,8 \\
\hline 40 & 22,4 & 20,3 & 18,2 & 16,2 & 22,6 & 20,6 & 18,7 & 16,7 \\
\hline 50 & 26,9 & 24,4 & 21,9 & 19,4 & 28,2 & 25,7 & 23,4 & 21,0 \\
\hline 60 & 30,6 & 27,7 & 24,9 & 22,1 & 32,9 & 30,1 & 27,4 & 24,7 \\
\hline 70 & 33,7 & 30,5 & 27,5 & 24,3 & 36,9 & 33,8 & 30,8 & 27,9 \\
\hline 80 & 36,2 & 32,8 & 29,5 & 26,2 & 40,3 & 36,9 & 33,7 & 30,5 \\
\hline 90 & 38,3 & 34,7 & 31,2 & 27,7 & 43,0 & 39,5 & 36,1 & 32,7 \\
\hline 100 & 40,0 & 36,3 & 32,6 & 28,9 & 45,3 & 41,6 & 38,1 & 34,5 \\
\hline 110 & 41,4 & 37,5 & 33,7 & 29,9 & 47,2 & 43,4 & 39,7 & 36,0 \\
\hline 120 & 42,5 & 38,5 & 34,7 & 30,7 & 48,8 & 44,8 & 41,0 & 37,2 \\
\hline
\end{tabular}

Динамічні ряди середніх висоти і діаметра деревостанів бука лісового

Середньоарифметичну висоту відображено лінійною моделлю $\mathrm{H}=0,9586 \times \mathrm{H}-0,5538$ (коефіцієнт детермінації $\mathrm{R}^{2}=99,53 \%$; показник точності моделі $\theta=99,76 \%$ ). Середньоквадратична висота описана лінійною моделлю $\mathrm{H}_{\mathrm{q}}=0,9641 \times \mathrm{H}-0,3892$ $\left(\mathrm{R}^{2}=99,98 \% ; \theta=99,99 \%\right)$. Середньоарифметичний діаметр адекватно відображено рівнянням прямої лінії $\mathrm{D}_{\mathrm{a}}=0,9524 \times \mathrm{D}-0,3559\left(\mathrm{R}^{2}=99,98 \% ; \theta=99,99 \%\right)$.

Теоретичні динамічні ряди середньоарифметичних висоти та діаметра, а також середньоквадратичної висоти для деревостанів Fagus sylvatica наведено в табл. 2.

Результати моделювання стандартного відхилення ряду висоти та діаметра для деревостанів бука наведено у табл. 3.

Абсолютне значення стандартного відхилення для ряду висоти менше від аналогічного показника ряду діаметра. Асиметрія характеризується високою мінливістю. Тому навіть після розділення в го- могенні ряди можливо подати модель лише найвірогідніших значень асиметрії. Здебільшого асиметрія не перевищує $\pm 0,80$. Аналіз експериментальних даних показав, що вища за модулем асиметрія не характерна для розподілів діаметра бука лісового. Виняток становлять молодняки цього деревного виду.

Модель асиметрії ряду діаметра для насаджень бука лісового описано формулою (10). Аналітично залежність між асиметрією розподілів діаметра та висоти букових насаджень описано лінійною моделлю (11):

$$
\begin{aligned}
r_{3 d}= & \left(3,41+0,031 \cdot 5-0,0016 \cdot D^{2}\right) . \\
& \cdot A^{-0,2236 \cdot \ln \left(3,41+0,031 \cdot 5-0,0016 b^{2}\right)-0,22}, \\
& r_{3 h}=0,6032 \cdot r_{3 d}-0,97,
\end{aligned}
$$

Найвірогідніші значення асиметрії розподілу кількості дерев за діаметром і за висотою наведено у табл. 4. 
Динаміка параметрів положення деревостанів бука лісового

Таблиия 2

\begin{tabular}{|c|c|c|c|c|c|c|c|c|c|c|c|c|}
\hline \multirow{3}{*}{$\begin{array}{l}\text { Середній вік, } \\
\text { років }\end{array}$} & \multicolumn{12}{|c|}{ Значення параметрів положення за класами бонітету } \\
\hline & $\mathrm{I}^{\mathrm{c}}$ & $\mathrm{I}^{\mathrm{b}}$ & $\mathrm{I}^{\mathrm{a}}$ & I & $\mathrm{I}^{\mathrm{c}}$ & $\mathrm{I}^{\mathrm{b}}$ & $\mathrm{I}^{\mathrm{a}}$ & I & $\mathrm{I}^{\mathrm{c}}$ & $\mathrm{I}^{\mathrm{b}}$ & $\mathrm{I}^{\mathrm{a}}$ & I \\
\hline & \multicolumn{4}{|c|}{ середньоарифм. висота, м } & \multicolumn{4}{|c|}{ середньоквадрат. висота, м } & \multicolumn{4}{|c|}{ середньоарифм. діаметр, см } \\
\hline 10 & 3,2 & 2,8 & 2,5 & 2,1 & 3,4 & 3,0 & 2,7 & 2,3 & 2,3 & 2,0 & 1,7 & 1,4 \\
\hline 20 & 9,6 & 8,7 & 7,8 & 6,8 & 9,9 & 8,9 & 8,0 & 7,0 & 8,5 & 7,6 & 6,8 & 5,9 \\
\hline 30 & 15,7 & 14,2 & 12,7 & 11,2 & 16,0 & 14,4 & 12,9 & 11,4 & 15,1 & 13,7 & 12,3 & 10,9 \\
\hline 40 & 20,9 & 18,9 & 16,9 & 14,9 & 21,2 & 19,2 & 17,2 & 15,2 & 21,2 & 19,3 & 17,4 & 15,6 \\
\hline 50 & 25,2 & 22,8 & 20,4 & 18,1 & 25,5 & 23,1 & 20,7 & 18,3 & 26,5 & 24,2 & 21,9 & 19,7 \\
\hline 60 & 28,8 & 26,0 & 23,4 & 20,6 & 29,1 & 26,4 & 23,7 & 20,9 & 31,0 & 28,3 & 25,8 & 23,2 \\
\hline 70 & 31,7 & 28,7 & 25,8 & 22,8 & 32,1 & 29,0 & 26,1 & 23,1 & 34,8 & 31,8 & 29,0 & 26,2 \\
\hline 80 & 34,2 & 30,9 & 27,7 & 24,5 & 34,5 & 31,3 & 28,1 & 24,8 & 38,0 & 34,8 & 31,7 & 28,7 \\
\hline 90 & 36,2 & 32,7 & 29,4 & 26,0 & 36,5 & 33,1 & 29,7 & 26,3 & 40,6 & 37,2 & 34,0 & 30,8 \\
\hline 100 & 37,8 & 34,2 & 30,7 & 27,1 & 38,2 & 34,6 & 31,0 & 27,5 & 42,8 & 39,3 & 35,9 & 32,5 \\
\hline 110 & 39,1 & 35,4 & 31,8 & 28,1 & 39,5 & 35,8 & 32,1 & 28,4 & 44,6 & 41,0 & 37,4 & 33,9 \\
\hline 120 & 40,2 & 36,4 & 32,7 & 28,9 & 40,6 & 36,8 & 33,0 & 29,2 & 46,1 & 42,3 & 38,7 & 35,1 \\
\hline
\end{tabular}

Динаміка стандартного відхилення для ряду висоти та діаметра

\begin{tabular}{|c|c|c|c|c|c|c|c|c|}
\hline \multirow{3}{*}{$\begin{array}{c}\text { Середній вік, } \\
\text { років }\end{array}$} & \multicolumn{8}{|c|}{ Значення стандартного відхилення за класами бонітету } \\
\hline & $\mathrm{I}^{\mathrm{c}}$ & $\mathrm{I}^{\mathrm{b}}$ & $\mathrm{I}^{\mathrm{a}}$ & I & $\mathrm{I}^{\mathrm{c}}$ & $\mathrm{I}^{\mathrm{b}}$ & $\mathrm{I}^{\mathrm{a}}$ & I \\
\hline & \multicolumn{4}{|c|}{ ряд висоти } & \multicolumn{4}{|c|}{ ряд діаметра } \\
\hline 10 & 1,1 & 1,0 & 1,0 & 0,9 & 1,6 & 1,5 & 1,3 & 1,2 \\
\hline 20 & 2,1 & 2,0 & 1,8 & 1,7 & 3,8 & 3,5 & 3,2 & 2,9 \\
\hline 30 & 2,9 & 2,7 & 2,5 & 2,3 & 6,0 & 5,5 & 5,0 & 4,6 \\
\hline 40 & 3,5 & 3,2 & 3,0 & 2,8 & 7,9 & 7,3 & 6,7 & 6,1 \\
\hline 50 & 4,0 & 3,7 & 3,4 & 3,1 & 9,6 & 8,9 & 8,2 & 7,4 \\
\hline 60 & 4,4 & 4,1 & 3,8 & 3,4 & 11,1 & 10,2 & 9,4 & 8,6 \\
\hline 70 & 4,7 & 4,4 & 4,0 & 3,7 & 12,3 & 11,4 & 10,4 & 9,5 \\
\hline 80 & 5,0 & 4,6 & 4,3 & 3,9 & 13,3 & 12,3 & 11,3 & 10,3 \\
\hline 90 & 5,2 & 4,8 & 4,5 & 4,1 & 14,2 & 13,1 & 12,1 & 11,0 \\
\hline 100 & 5,4 & 5,0 & 4,6 & 4,2 & 14,9 & 13,7 & 12,7 & 11,6 \\
\hline 110 & 5,6 & 5,1 & 4,7 & 4,3 & 15,5 & 14,3 & 13,2 & 12,0 \\
\hline 120 & 5,7 & 5,2 & 4,8 & 4,4 & 15,9 & 14,7 & 13,6 & 12,4 \\
\hline
\end{tabular}

Таблиия 4

Динаміка асиметрії розподілу кількості дерев за діаметром та за висотою

\begin{tabular}{ccccc|cccc}
\hline \multirow{2}{*}{$\begin{array}{c}\text { Середній вік, } \\
\text { років }\end{array}$} & $\mathrm{I}^{\mathrm{c}}$ & \multicolumn{7}{c}{ Значення асиметрії за класами бонітету } \\
\cline { 2 - 10 } & \multicolumn{7}{c}{$\mathrm{I}^{\mathrm{b}}$} & \multicolumn{2}{c}{$\mathrm{I}^{\mathrm{a}}$} & $\mathrm{I}$ & $\mathrm{I}^{\mathrm{c}}$ & $\mathrm{I}^{\mathrm{b}}$ & $\mathrm{I}^{\mathrm{a}}$ & $\mathrm{I}$ \\
\hline 1 & 2 & 3 & 4 & 5 & 6 & 7 & 8 & ряд діаметра висоти \\
\hline 10 & $-0,46$ & $-0,42$ & $-0,39$ & $-0,36$ & 0,86 & 0,92 & 0,98 & 1,02 \\
20 & $-0,58$ & $-0,56$ & $-0,54$ & $-0,53$ & 0,66 & 0,69 & 0,72 & 0,74 \\
30 & $-0,64$ & $-0,62$ & $-0,61$ & $-0,61$ & 0,56 & 0,58 & 0,60 & 0,61 \\
\hline
\end{tabular}




\begin{tabular}{|c|c|c|c|c|c|c|c|c|}
\hline & & & & & & & \multicolumn{2}{|c|}{ Продовж. табл. 4} \\
\hline 1 & 2 & 3 & 4 & 5 & 6 & 7 & 8 & 9 \\
\hline 40 & $-0,67$ & $-0,66$ & $-0,66$ & $-0,65$ & 0,50 & 0,52 & 0,53 & 0,53 \\
\hline 50 & $-0,70$ & $-0,69$ & $-0,69$ & $-0,68$ & 0,46 & 0,47 & 0,48 & 0,48 \\
\hline 60 & $-0,72$ & $-0,71$ & $-0,71$ & $-0,71$ & 0,43 & 0,43 & 0,44 & 0,44 \\
\hline 70 & $-0,73$ & $-0,73$ & $-0,73$ & $-0,73$ & 0,40 & 0,41 & 0,41 & 0,41 \\
\hline 80 & $-0,74$ & $-0,74$ & $-0,74$ & $-0,74$ & 0,38 & 0,39 & 0,39 & 0,39 \\
\hline 90 & $-0,75$ & $-0,75$ & $-0,75$ & $-0,75$ & 0,37 & 0,37 & 0,37 & 0,37 \\
\hline 100 & $-0,76$ & $-0,76$ & $-0,76$ & $-0,76$ & 0,35 & 0,35 & 0,35 & 0,35 \\
\hline 110 & $-0,77$ & $-0,77$ & $-0,77$ & $-0,77$ & 0,34 & 0,34 & 0,33 & 0,33 \\
\hline 120 & $-0,78$ & $-0,78$ & $-0,78$ & $-0,78$ & 0,33 & 0,32 & 0,32 & 0,32 \\
\hline
\end{tabular}

За аналізом наведених в табл. 4 даних, асиметрія ряду діаметра в динаміці є додатна і найбільша в молодняках. Асиметрія в цій віковій групі за величиною $є$ сильною або середньою. В інших вікових групах асиметрія діаметрів слабка або середня.

Аналіз значень для рядів висот (див. табл. 4) показує, що величина асиметрії від'ємна і найменша в букових молодняках. Абсолютна величина асиметрії розподілу ймовірностей висоти бука загалом $\epsilon$ більшою ніж 0,35 .

На відміну від розподілу діаметра, мінімальна величина асиметрії висоти припадає на молодняки першого десятиріччя. В інших класах віку асиметрія розподілу висоти $є$ від'ємною, а за ступенем - середньою та сильною. Параметр косості кривої розподілу має винятково важливе значен- ня для характеристики сортиментної структури насадження. Дослідження вказаних параметрів математично пояснює особливості та закономірності товарно-сортиментної структури деревостану.

Аналітичний вираз, на основі якого вирівняно найімовірніші значення четвертого основного моменту розподілу діаметра (висоти) для деревостанів бука лісового, виражено експоненціальним рівнянням (12)-(13):

$$
\begin{gathered}
r_{4 h}=1,7747 \cdot \operatorname{EXP}\left(-0,7276 \cdot r_{3 h}\right), \\
r_{4 d}=2,1071 \cdot \operatorname{EXP}\left(0,5999 \cdot r_{3 d}\right),
\end{gathered}
$$

Розрахунок найвірогідніших значень четвертого основного моменту для розподілу діаметра наведено у табл. 5.

Таблиия 5

\begin{tabular}{|c|c|c|c|c|c|c|c|c|}
\hline \multirow{3}{*}{$\begin{array}{l}\text { Середній вік, } \\
\text { років }\end{array}$} & \multicolumn{8}{|c|}{ Значення четвертого основного моменту за класами бонітету } \\
\hline & $\mathrm{I}^{\mathrm{c}}$ & $\mathrm{I}^{\mathrm{b}}$ & $\mathrm{I}^{\mathrm{a}}$ & I & $\mathrm{I}^{\mathrm{c}}$ & $\mathrm{I}^{\mathrm{b}}$ & $\mathrm{I}^{\mathrm{a}}$ & I \\
\hline & \multicolumn{4}{|c|}{ ряд висоти } & \multicolumn{4}{|c|}{ ряд діаметра } \\
\hline 10 & 2,47 & 2,40 & 2,35 & 2,31 & 3,53 & 3,67 & 3,78 & 3,88 \\
\hline 20 & 2,70 & 2,66 & 2,63 & 2,61 & 3,12 & 3,19 & 3,24 & 3,28 \\
\hline 30 & 2,82 & 2,79 & 2,77 & 2,76 & 2,95 & 2,99 & 3,02 & 3,04 \\
\hline 40 & 2,89 & 2,88 & 2,86 & 2,85 & 2,85 & 2,87 & 2,89 & 2,90 \\
\hline 50 & 2,95 & 2,93 & 2,93 & 2,92 & 2,78 & 2,79 & 2,80 & 2,81 \\
\hline 60 & 2,99 & 2,98 & 2,97 & 2,97 & 2,73 & 2,73 & 2,74 & 2,75 \\
\hline 70 & 3,02 & 3,02 & 3,01 & 3,01 & 2,69 & 2,69 & 2,69 & 2,70 \\
\hline 80 & 3,05 & 3,05 & 3,04 & 3,04 & 2,65 & 2,65 & 2,66 & 2,66 \\
\hline 90 & 3,07 & 3,07 & 3,07 & 3,07 & 2,63 & 2,63 & 2,62 & 2,62 \\
\hline 100 & 3,09 & 3,09 & 3,09 & 3,09 & 2,60 & 2,60 & 2,60 & 2,60 \\
\hline 110 & 3,11 & 3,11 & 3,11 & 3,12 & 2,58 & 2,58 & 2,58 & 2,57 \\
\hline 120 & 3,12 & 3,13 & 3,13 & 3,13 & 2,57 & 2,56 & 2,56 & 2,55 \\
\hline
\end{tabular}

Динаміка четвертого основного моменту розподілу діаметра і висоти

У динаміці величина четвертого основного моменту в молодняках $\epsilon$ вищою, ніж у стиглих насадженнях. За знаком цей параметр різний, проте коливається довкола нуля. Загалом для досліджува- них розподілів параметр ексцесу за абсолютним значенням $€$ незначним.

Аналіз даних табл. 5 свідчить про те, що значення четвертого основного моменту розподілу ймо- 
вірностей висоти зростає у динаміці. Амплітуда коливання значень цього параметра щодо бонітету менша, ніж у розподілу кількості дерев за діаметром. Порівняння значень параметра ексцесу розподілів ймовірностей висоти та діаметра дає змогу виявити в них обернено пропорційний зв'язок між $\mathrm{r}_{4 \mathrm{~h}}$ та $\mathrm{r}_{4 \mathrm{~d}}$ у бука лісового.

Параметр зв'язку $\left(\mathrm{r}_{11}\right)$ достатньо вивчений. Так, в одновікових сосняках співвідношення між таксаційними ознаками із застосуванням кореляційного аналізу в період 1926-1936 рр. аналізував у наукових працях А.І. Кондратьєв (Цурик, 2001). Пізніше цей науковий напрям поглиблювали В.І. Лєвін впродовж 1955-1966 рр., М. Л. Дворецький - 19571964 рр., А. В. Рогачов, Н. Т. Смірнов, П. М. Верхунов - у 70-их роках минулого століття.

У своїх наукових працях К. С. Нікітін, А. З. Швиденко (1978) встановили величину показника кореляції між діаметром і висотою ялинових деревостанів. За їхніми даними, для нижньогірського лісорослинного поясу кореляція становить $0,79 \pm 0,038$,

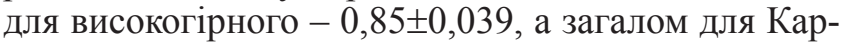
пат $-0,73 \pm 0,039$.

Парний коефіцієнт кореляції між діаметром та висотою у Карпатських ялинниках оцінено також Є.І. Цуриком (2001). За результатами досліджень, в умовно одновікових деревостанах цей показник становить $0,79 \pm 0,022$, в умовно різновікових $-0,86 \pm 0,020$, у різновікових $-0,84 \pm 0,017$. Розрахований коефіцієнт кореляції розподілу діаметра та висоти деревостану сосни 180-річного віку за А.К. Митропольським (1961) становить 0,73.

Аналіз власних спостережень свідчить про деяку зміну коефіцієнта кореляції у динаміці. Загальний вигляд моделі залежності параметра зв'язку від віку деревостану для бука лісового виражається рівнянням (14):

$$
r_{11}=0,726-0,0004 \cdot A,
$$

Аналіз емпіричних значень коефіцієнта кореляції на таксаційних пробних площах дає підставу стверджувати, що нижня межа рідко опускається нижче 0,68 , а верхня - не перевищує 0,84 .

Створивши масив інформації за допомогою групування параметрів $\mathrm{r}_{21}, \mathrm{r}_{12}, \mathrm{r}_{13}, \mathrm{r}_{31}$ та $\mathrm{r}_{22}$ щодо різних факторів, вибрано найвагоміші 3 них. Для апроксимації вказаних параметрів найкраще використати їхній прямолінійний зв’язок. Загальний вигляд моделей залежності параметрів описано рівняннями для деревостанів бука (15)-(19):

$$
\begin{aligned}
& r_{12}=0,6263 \cdot r_{03}-0,0127, \\
& r_{21}=0,5947 \cdot r_{30}-0,3125, \\
& r_{13}=0,3955 \cdot r_{04}+0,8945, \\
& r_{31}=0,2076 \cdot r_{40}-1,3706, \\
& r_{22}=0,3688 \cdot r_{13}+1,0917,
\end{aligned}
$$

У підсумку, середнє значення параметра $\mathrm{r}_{12}$ ста-

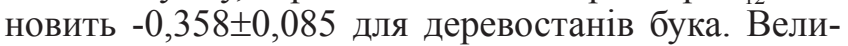
чина та знак параметра вказують, що середня по- верхня буде скошена праворуч від лінії регресії висоти. Знак параметра $\mathrm{r}_{12}$ поверхні здебільшого збігається зі знаком асиметрії розподілу висоти.

Середнє значення параметра $\mathrm{r}_{21}$ для деревоста-

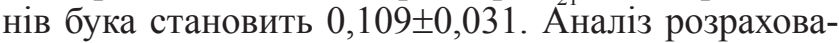
них параметрів підтверджує, що $\mathrm{r}_{21}$ за абсолютним значенням є меншим, ніж величина параметра $\mathrm{r}_{12}$. В обох випадках параметри характеризуються знаком «мінус».

Наступні параметри відображають особливості концентрації ймовірностей з урахуванням одночасно двох систем випадкових величин. Міра концентрації кількості дерев змінює піднятість вершини поверхні розподілу.

Розрахунок параметра $r_{13}$ показав, що його середнє значення для деревостанів бука становить $2,198 \pm 0,422$. Узагальнюючи значення параметра $\mathrm{r}_{31}$, загалом для всіх класів віку виведено його серед-

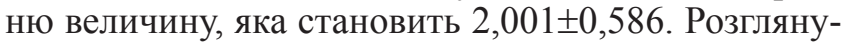
ті параметри набувають додатних значень.

Другий основний змішаний момент $r_{22}$ характеризує площу еліпса розсіювання двох випадкових величин. Він описує проекцію поверхні розподілу на площину, утворену осями абсцис та ординат. За математичною суттю параметр $\mathrm{r}_{22} \epsilon$ аналогічним дисперсії i, залежно від його величини, змінюється й масштаб поверхні розподілу ймовірностей за висотою та діаметром.

У букових деревостанах параметр $r_{22}$ набуває значення від 1,900 до 2,100. Оптимізуючи результат, отримаємо середнє значення параметра, який

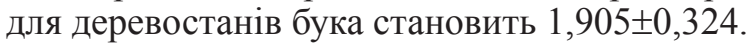

Аналіз табульованих значень параметра масштабу розподілу ймовірностей діаметра та висоти дає змогу визначити лімітуючі величини. Нижня межа цього параметра не опускається нижче 1,700. Верхньою межею другого основного змішаного моменту, незалежно від внесених у модель факторів, $є$ значення 2,500.

Оцінювання особливостей форми поверхні розподілу ймовірностей за діаметром і висотою дерев у динаміці, залежно від класу бонітету, є теоретичною основою розрахунку обсягів запасу і відпаду у насадженнях. Моделювання двовимірного розподілу кількості дерев за діаметром та висотою можна використати під час аналізу товарної структури деревостану, виходу ділових сортиментів та їх матеріально-грошового оцінення. Розв'язання зазначених вище завдань на новій методичній основі з використанням динамічних рядів апроксимованих параметрів за допомогою введення їх у модель поверхні типу А дає змогу отримати розподіл запасу деревини щодо ступенів діаметра та висоти.

Фрагмент двовимірного теоретичного розподілу кількості дерев за діаметром і висотою для 80-річних деревостанів Fagus sylvatica у найпродуктивніших лісорослинних умовах $\left(D_{2}\right)$ наведено у табл. 7.

Двовимірний теоретичний розподіл частот діаметра і висоти можна використати як базовий для комплексного оцінювання усіх компонентів дере- 
востану. Зокрема, можливе доповнення моделями для розрахунку маси, протяжності та об'єму коренів залежно від віку, діаметра і висоти дерев, опрацьованих М.М. Гузем (1996). Практичне значен- ня цих досліджень полягає в оцінюванні запасу кореневої деревини як можливого джерела сировини промислового значення, а також як джерела поповнення елементів родючості грунту.

Таблиия 7

Теоретичний розподіл кількості дерев у 80-річних букових деревостанах свіжого груду (I'

\begin{tabular}{|c|c|c|c|c|c|c|c|c|c|c|c|c|c|c|c|}
\hline \multirow{2}{*}{$d_{i}$} & \multicolumn{15}{|c|}{$h_{j}$} \\
\hline & 20 & 22 & 24 & 26 & 28 & 30 & 32 & 34 & 36 & 38 & 40 & 42 & 44 & 46 & 48 \\
\hline 12 & 0,10 & 0,17 & 0,25 & 0,33 & 0,37 & 0,29 & 0,14 & 0,04 & 0,01 & & & & & & \\
\hline 16 & 0,12 & 0,26 & 0,42 & 0,57 & 0,70 & 0,67 & 0,43 & 0,17 & 0,04 & 0,00 & & & & & \\
\hline 20 & 0,11 & 0,28 & 0,53 & 0,79 & 1,05 & 1,19 & 0,97 & 0,50 & 0,15 & 0,02 & & & & & \\
\hline 24 & 0,07 & 0,24 & 0,54 & 0,89 & 1,27 & 1,64 & 1,66 & 1,13 & 0,46 & 0,10 & 0,01 & & & & \\
\hline 28 & 0,04 & 0,15 & 0,43 & 0,82 & 1,25 & 1,79 & 2,22 & 1,95 & 1,06 & 0,33 & 0,05 & & & & \\
\hline 32 & 0,01 & 0,08 & 0,27 & 0,62 & 1,03 & 1,58 & 2,32 & 2,62 & 1,89 & 0,80 & 0,17 & 0,00 & & & \\
\hline 36 & 0,00 & 0,03 & 0,14 & 0,38 & 0,71 & 1,14 & 1,91 & 2,75 & 2,63 & 1,50 & 0,46 & 0,04 & & & \\
\hline 40 & & 0,01 & 0,06 & 0,19 & 0,41 & 0,69 & 1,25 & 2,27 & 2,88 & 2,19 & 0,92 & 0,16 & & & \\
\hline 44 & & 0,00 & 0,02 & 0,08 & 0,20 & 0,36 & 0,67 & 1,48 & 2,51 & 2,55 & 1,45 & 0,39 & & & \\
\hline 48 & & & 0,00 & 0,02 & 0,08 & 0,16 & 0,29 & 0,77 & 1,75 & 2,40 & 1,83 & 0,70 & 0,06 & & \\
\hline 52 & & & & 0,01 & 0,03 & 0,06 & 0,11 & 0,32 & 0,99 & 1,83 & 1,86 & 0,99 & 0,19 & & \\
\hline 56 & & & & & 0,01 & 0,02 & 0,04 & 0,11 & 0,46 & 1,14 & 1,54 & 1,12 & 0,35 & & \\
\hline 60 & & & & & & 0,00 & 0,01 & 0,03 & 0,17 & 0,59 & 1,05 & 1,02 & 0,48 & 0,03 & \\
\hline 64 & & & & & & & 0,00 & 0,01 & 0,05 & 0,25 & 0,58 & 0,75 & 0,50 & 0,11 & \\
\hline 68 & & & & & & & & & 0,01 & 0,09 & 0,26 & 0,44 & 0,40 & 0,16 & \\
\hline 72 & & & & & & & & & 0,00 & 0,02 & 0,10 & 0,21 & 0,26 & 0,16 & 0,02 \\
\hline 76 & & & & & & & & & & 0,01 & 0,03 & 0,08 & 0,13 & 0,11 & 0,04 \\
\hline
\end{tabular}

Моделями оцінювання компонентів надземної фітомаси дерев (гілок та деревної зелені), опрацьованих П. І. Лакидою (1997, 2001), можливо доповнити інформацією щодо асимілятивної частини дерева та деревостану. Внаслідок поєднання вказаних моделей існує змога отримати цілісне уявлення про структуру компонентів деревостану у динаміці.

Висновки. Таксаційна будова нормальних букових деревостанів Ic...I класів бонітету відображає розподіл кількості дерев за діаметром і висотою в діапазоні 10-120 років.

Моделлю розподілу кількості дерев за висотою та діаметром є 14-ти параметрична поверхня розподілу ймовірностей типу А. Алгоритм моделювання теоретичної поверхні містить розрахунок таких параметрів: розподілу діаметра та висоти: положення (середньоарифметичні та середньоквадратичні показники), масштабу (стандартні відхилення), форми (асиметрію та ексцес), зв’ язку (основні змішані моменти 1-3 порядків).

У деревостанах Fagus sylvatica 10-річного та 120-річного віку стандартне відхилення розподілу кількості дерев за висотою збільшуються 3 1,1 ...0,9 до $5,7 \ldots 4,4$ м; стандартне відхилення розподілу кількості дерев за діаметром зростає з 1,6...1,2 до $15,9 \ldots 12,4$ см; асиметрія розподілу кількості дерев за висотою посилюється $3-0,46 \ldots-0,36$ до -0,78; асиметрія розподілу кількості дерев за діаметром послаблюється з 0,86...1,02 до 0,33...0,32; ексцес розподілу кількості дерев за висотою посилюється $3-0,53 \ldots-0,69$ до $0,12 \ldots 0,13$; ексцес розподілу кількості дерев за діаметром послаблюється $з$ 0,53...0,88 до -0,43...-0,45. Коефіцієнт кореляції між ознаками в середньому становить 0,76. Найвірогідніші значення інших основних змішаних моментів такі: $\mathrm{r}_{12}=-0,358, \mathrm{r}_{21}=-0,109, \mathrm{r}_{13}=2,198$, $\mathrm{r}_{31}=2,001, \mathrm{r}_{22}=1,905$.

Аргументами моделі динаміки параметрів положення $є$ середні значення висоти та діаметра букового деревостану. Середня висота деревостану $є$ функцією верхньої висоти. Аргументами моделі динаміки параметрів форми розподілу ознак $є$ середній вік і клас бонітету насадження. Складні змішані моменти визначено через показники простіших параметрів. Результатом моделювання згаданих параметрів є нормативи динаміки двовимірного розподілу кількості дерев за висотою та діаметром для деревостанів бука лісового I ${ }^{\mathrm{c}}$...I класів бонітету.

Моделювання багатовимірних залежностей дає можливість розв'язувати практичні завдання. Розрахунок запасу деревостану, здійснений із застосу- 
ванням моделі багатовимірного розподілу, дає змогу отримати більшу кількість об'єктивної лісівничої інформації про його сортиментну й товарну структуру. Застосування методу багатовимірного оцінювання розподілу висоти й діаметра у різному віці, у різних лісорослинних умовах дає змогу формалізувати проектування рубок догляду.

Дослідження з метою створення багатовимірних стохастичних моделей дають змогу математично зв'язати стовбурову, підземну та асимілятивну частини деревостану, що сприяє створенню цілісного уявлення про ліс, як систему з усією різноманітністю вимірів та зв'язків.

\section{Список літератури}

Вентцель Е.С. (2001). Теория вероятностей. Москва: Высшая школа. 575 с. [Venttsel, E.S. (2001). Theory of probability. Moscow: Higher school] (in Russian)

Гузь М.М. (1996). Закономірності формування кореневих систем лісоутворюючих порід України. Львів: УкрДЛТУ. 39 с. [Huz, М. М. (1996). The regularities of rootage forming of main species of Ukraine. Lviv: Ukrainian State Forestry University] (in Ukrainian)

Лакида П.І. (1997). Продуктивність лісових насаджень України за компонентами надземної фітомаси. Київ: НАУ. 48 с. [Lakyda, P. I. (1997). Productivity of forest stands of Ukraine by the components of above ground phytomass. Kyiv: National Agrarian University] (in Ukrainian)

Лакида П. І. (2001). Фітомаса лісів Украӥни. Тернопіль: Збруч. 256 с. [Lakyda, P. I. (2001). Phytomass of the forests of Ukraine. Ternopil: Zbruch] (in Ukrainian)

Митропольский А.К. (1961). Техника статистических вычислений. Москва: Госиздат физ.-мат. лит-ры. 480 с. [Mytropolskyi, А. К. (1961). Technology of statistical calculations. Moscow: State publisher of physical and mathematical literature] (in Russian)

Никитин К.Е., Швиденко А.З. (1978). Методь и техника обработки лесоводственной информации. Москва: Лесная промышленность. 272 с. [Nikitin, K.E., \& Shvydenko, A.Z. (1978). Methods and technology of development of forestry information. Moscow: Forest industry] (in Russian)

Третьяков Н.В. (1927). Закон единства в строении насаждений. Москва-Ленинград: Новая деревня. 113 c. [Tretiakov, A.V. (1923). The law of unity in the structure of plantations. Moscow-Leningrad: New Village] (in Russian)

Фелив А.А. (1978). Рост, строение и динамика товарности буковых древостоев северного мегасклона Украинских Карпат. Москва: Московский лесотехнический институт. 24 c. [Felyv, A.A. Growth, structure and dynamic of commodity of beech stands of northern mega slope of Ukrainian Carpathian. Moscow: Moscow Forestry University] (in Russian)

Цурик С. I. (2001). Таксаиійні ознаки й будова насаджень. Львів: УкрДЛТУ. 362 с. [Tsuryk, Ye. I. (2001).
Forest valuation indexes and structure of stands. Lviv: Ukrainian State Forestry University] (in Ukrainian)

Яглом А.М., Яглом И.М. (1973). Вероятность и информация. Москва: Наука. 512 с. [Yahlom, А. М., \& Yahlom, I.M. (1973). Probability and information. Moscow: Science] (in Russian)

Adam, R. M., Grant M. D., Doraisami, M., \& Sean C.T. (2021). Carbon fractions in the world's dead wood. Nature communications, 12(889), 1-9. https://doi. org/10.1038/s41467-021-21149-9

Sens, R., Spracklen, B., \& Spracklen, D. V. (2021). Determination of Structural Characteristics of OldGrowth. Remote Sens, 13(1233), 1-21 https://doi. org/10.3390/rs13071233

Ehbrecht, M., Seidel, D., Annighцfer, P., Kreft, H., Kühler, M., Zemp, D.C., ... Ammer, Ch. (2021). Global patterns and climatic controls of forest structural complexity. Nature communications, 12(519), 1-12. https://doi.org/10.1038/s41467-02020767-Z

Meyer, P., Aljes, M., Culmsee, H., Feldmann, E., Glatthorn, J., Leuschner, Ch., \& Schneider, H. (2021). Quantifying old-growthness of lowland European beech forests by a multivariate indicator for forest structure. Ecological Indicators, 125(107575), 1-14. https://doi.org/10.1016/j.ecolind.2021.107575

Dudek, T., Korol, M., Havryliuk, S., Dychkevych, V., \& Bobiec, A. (2021). The dendrometric characteristics of oak woods in rural landscapes of the East Carpathians. Baltic Forestry, 27(1), 1-8. https://doi. org/10.46490/BF336https://doi.org/10.46490/BF336

\section{Multivariate beech stands structure in the north-east mega slope of the Ukrainian Carpathian: theoretical aspects and practical significance}

High productivity even-aged beech stands of the north-east mega slope of the Ukrainian Carpathian in different age are the study object in this scientific work.

Yulian Kahaniak - Full Member of the Forestry Academy of Sciences of Ukraine, Doctor of Agricultural Sciences, Professor of the Forest Inventory and Forest Management Department. Ukrainian National Forestry University. Hen. Chuprynka str., 103, Lviv, 79057, Ukraine. Tel.: +38-096-057-11-96. E-mail: y.kahanjak@nltu.edu.ua ORCID: http://orcid.org/0000-0002-9215-3922

Ivan Ilkiv - PhD of Agricultural Science, Head of the Forest Inventory and Forest Management Department. Ukrainian National Forestry University. Hen. Chuprynka str., 103, Lviv, 79057, Ukraine. Tel.: +38-067-926-45-61. E-mail: i.ilkiv@nltu.edu.ua ORCID: https://orcid.org/0000-0002-8863-8708

Serhii Havryliuk - PhD of Agricultural Science, Associate Professor of the Forest Inventory and Forest Management Department. Ukrainian National Forestry University. Hen. Chuprynka str., 103, Lviv, 79057, Ukraine. Tel.: +38-068-760-91-99. E-mail: serhiy_ havrylyuk@nltu.edu.ua ORCID: https://orcid.org/ 0000-00030361-0624 
The modelling of diameters and heights frequencies distribution performed taking into consideration their relations in dynamic for the detailing of information about the beech forest structure in the study region. The initial data were received by the continuous inventory method. This data includes measure of diameters and heights of beech trees. The age range of investigated stands was from 10 to 120 years.

The main parameters of one-dimensional distribution model are the mathematical expectation, standard deviation, skewness and kurtosis. When more complicate system is studied he model getting more complicate and the number of parameters, that describe it, is growing. Therefore, for modelling of diameter and height distribution, taking into account the relations between them, it is necessary to employ from 5 to 14 parameters.

The equation of fitted surface type A with 14 parameters was chosen as the model of diameters and heights distribution. The algorithm of modelling theoretical surface has the evaluation of such parameters of diameter and height distribution: position (mean and mean-square parameters), scale (standard deviations), form (skewness and kurtosis), relation (main mixed moments of 1-3 degree).

It is determined, that the standard deviation of tree's count deviation by height are increasing from $1,1 \ldots 0,9 \mathrm{~m}$ in 10 -year-old stands to $5,7 \ldots 4,4 \mathrm{~m}$ at 120 -year-old stands. The standard deviation of tree's count deviation by diameters are increasing from $1,6 \ldots 1,2 \mathrm{~cm}$ in 10 -year-old stands to $15,9 \ldots 12,4 \mathrm{~m}$ at 120 -year-old stands. The skewness of tree's count deviation by height are increasing from $-0,46 \ldots-0,36$ in 10-year-old stands to $-0,78$ at 120 -year-old stands. The skewness of tree's count deviation by diameter are decreasing from $0,86 \ldots 1,02$ in 10-year-old stands to $0,33 \ldots 0,32$ at 120 -year-old stands. The kurtosis of tree's count deviation by height are decreasing from $-0,53 \ldots-0,69$ in 10 -year-old stands to $0,12 \ldots 0,13$ at 120 -year-old stands. The kurtosis of tree's count deviation by diameter are decreasing from $0,53 \ldots 0,88$ in 10 -year-old stands to $-0,43 \ldots-0,45$ at 120 -yearold stands. The coefficient of correlation between the features is in average 0,76. Most veritable values of others main mixed moments are the next: $\mathrm{r}_{12}=-0,358$, $\mathrm{r}_{21}=-0,109, \mathrm{r}_{13}=2,198, \mathrm{r}_{31}=2,001, \mathrm{r}_{22}=1,905$.

The height and diameter parameters of beech stands were the model's independent variables of dynamic of state parameters. The average height of stand is a function of top height. The average age and productivity class of stands are the model's independent variables of dynamic of form. Complex mixed moments were evaluated through the variables of more simple parameters. The result of these modelling are the dynamic standards of two-dimensional distribution of quantity of trees by height and diameter for the beech stands of $I^{\mathrm{c}} \ldots$... classes of productivity.

The modelling of multi-dimensional relations allows to solve the practical tasks. The stands volume calculation was performed using a multivariate distribution model, which allows expanding the information base of the assortment and commodity structures. Application of the method of multivariate estimation of diameters and heights distribution in different ages, forest types and different productivity classes give an opportunity to formalize projecting of thinning.

The study for estimation of multivariate random models gives an opportunity to link the stem, underground and above-ground parts of the stands. This study will assist in developing a complete conception of the forest with a multiplicity of dimensions and relations.

Key words: density function, distribution, theoretical surface, parameters, forest structure, stand, beech, dynamic, relation.

\section{Многомерное строение буковых древостоев северно-восточного мегасклона Украинских Карпат: теоретические аспекты и практическое значение}

\section{Ю.И. Каганяк' , И.С. Илькив², С. А. Гаврилюк ${ }^{3}$}

Исследованы высокополнотные одновозрастные высокопродуктивные буковые древостои разного возраста на северо-восточном мегасклоне Украинских Карпат. Предметом исследования предусмотрено изучение таксационного строения объекта. Целью исследования является моделирование распределения частот диаметров и высот с учётом их связи в динамике для детализации информации о строении буковых древостоев указанного региона исследования.

Моделью распределения диаметров и высот избрано уравнение аппроксимирующей поверхности типа А. Функция плотности распределения вероят-

Каганяк Юлиан Иосифович - академик Лесной академии наук Украины, доктор сельскохозяйственных наук, профессор кафедры лесной таксации и лесоустройства. Национальный лесотехнический университет Украины, ул. Генерала Чупринки, 103, г. Львов, 79057, Украина. Тел.: +38-096-05711-96. E-mail: y.kahanjak@nltu.edu.ua ORCID: http://orcid. org/0000-0002-9215-3922

Илькив Иван Стефанович - кандидат сельскохозяйственных наук, заведующий кафедрой лесной таксации и лесоустройства. Национальный лесотехнический университет Украины, ул. Генерала Чупринки, 103, г. Львов, 79057, Украина. Тел.: +38-067-926-45-61. E-mail: i.ilkiv@nltu.edu.ua ORCID: https:// orcid.org/0000-0002-8863-8708

Гаврилюк Сергей Анатольевич - кандидат сельскохозяйственных наук, доцент кафедры лесной таксации и лесоустройства. Национальный лесотехнический университет Украины, ул. Генерала Чупринки, 103, г. Львов, 79057, Украина. Тел.: +38-068-760-91-99. E-mail: serhiy_havrylyuk@nltu.edu.ua ORCID: https://orcid.org/ 0000-0003-0361-0624 
ностей этой модели отображается 14 параметрами. Распределение диаметров (высот) оценено среднеарифметической величиной, стандартным отклонением, асимметрией и эксцессом, а также шестью параметрами, которые связывают указанные распределения и позволяют смоделировать теоретическую поверхность.

Среднеарифметическая и среднеквадратическая высоты, среднеарифметический диаметр отображаются линейной моделью. Теоретические значения параметров положения использовано для расчёта стандартного отклонения. Асимметрию ряда диаметра описано степенной функцией в зависимости от бонитета и среднего возраста. Теоретическую зависимость между асимметриями распределения диаметров и высот выражено линейной моделью. Четвертый основной момент распределения диаметров (высот) выражается экспоненциальным уравнением в зависимости от асимметрии. Среднее значение коэффициента корреляции составляет $0,76 \pm 0,011$. В среднем значение параметра $\mathrm{r}_{12}$ составляет $0,36 \pm 0,085, \mathrm{r}_{21}-0,11 \pm 0,031, \mathrm{r}_{13}-2,2 \pm 0,422$, $r_{31}-2,00 \pm 0,586, r_{22}-1,91 \pm 0,324$.

В результате моделирования 14 параметров аппроксимирующей поверхности типа А построены двухмерные распределения частот по диаметру и высоте. Теорию таксационного строения дополнено распределениями высот, учитывая связь с диаметрами в динамике. Поверхность распределения частот диаметров и высот описывает структуру высокополнотных буковых древостоев Ic-II класса бонитета в диапазоне среднего возраста от 10 до 120 лет.

Полученные результаты имеют практическое применение. Расчёт запаса древостоя на основании модели многомерного распределения расширяет информационный базис сортиментации и товаризации. Применение метода многомерной оценки распределения высот и диаметров в буковых древостоях разного среднего возраста, в разных лесорастительных условиях и для различных классов бонитета формализует проектирование рубок ухода.

Исследования по созданию многомерных стохастических моделей позволяют математически увязать стволовую, подземную и ассимиляционную части древостоя. Это направление обеспечивает создание целостного представления о лесе, как системе со всей разнообразностью измерений и связей.

Ключевые слова: функция плотности; распределение; теоретическая поверхность; параметры; древостой; динамика; связь. 